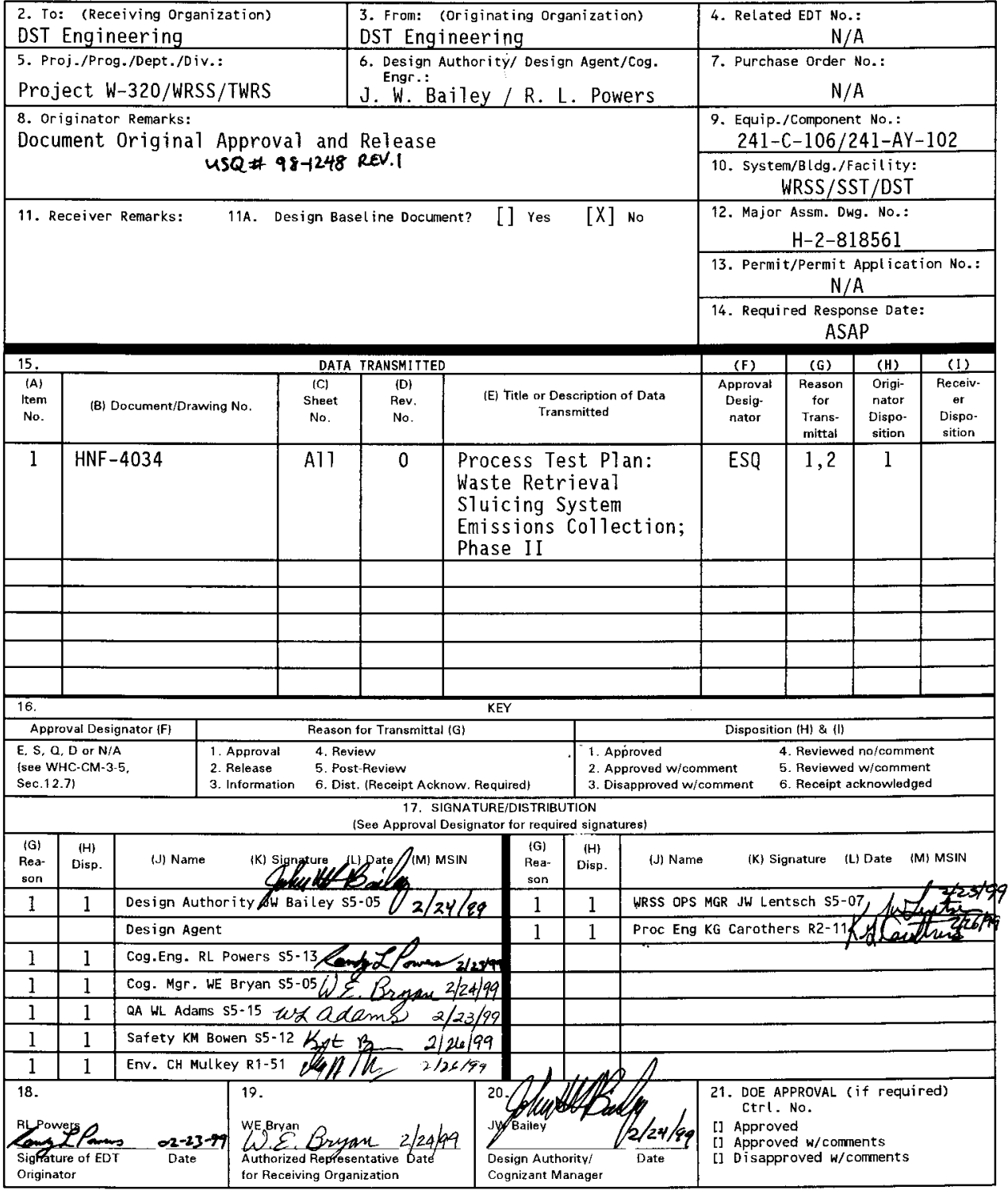


HNF-4034, Rev. 0

\section{PROCESS TEST PLAN, PHASE II: WASTE RETRIEVAL SLUICING SYSTEM EMISSIONS COLLECTION}

\section{R. L. Powers}

Lockheed Mart in Hanford Corporation, Richland, WA 99352

U.S. Department of Energy Contract DE-AC06-96RL13200
EDT/ECN: EDT\# 623252
UC: 506
Org Code: 74110
B\&R Code: EW3130010
Charge Code: CACN\# 101997
Total Pages: 30

Key Words: WRSS, 241-C-106, 241-AY-102, Sluicing, 296-C-006 Vapor Emissions, Total Organic Carbon (TOC)

Abstract: This Process Test Plan is prepared to continue from HNF-3733 which was Phase I of the test. Supplemental operational controls and sampling requirements are defined to safely obtain gas samples from the 296-C-006 ventilation system stack during active operation of the sluicing equipment.

TRADEMARK DISCLAIMER. Reference herein to any specific commercial product, process, or service by trade name, trademark, manufacturer, or otherwise, does not necessarily constitute or imply its endorsement, recommendation, or favoring by the United States Government or any agency thereof or its contractors or subcontractors.

Printed in the United States of America. To obtain copies of this document, contact: Document Control Services, P.O. Box 950, Mailstop H6-08, Richland WA 99352, Phone (509) 372-2420; Fax $(509)$ 376-4989.
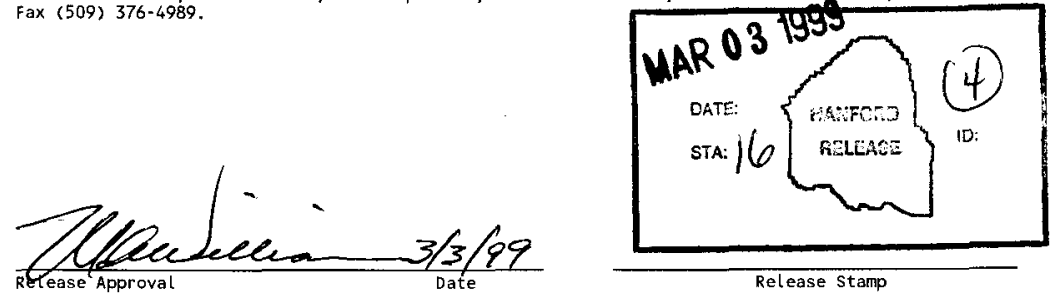


$$
\text { HNF-4034 Revision } 0
$$

PROCESS TEST PLAN, PHASE II:

\section{WASTE RETRIEVAL SLUICING SYSTEM EMISSIONS COLLECTION}

March 1999

Randy L. Powers

Double-She11 Tank Engineering

Lockheed Martin Hanford Company

P. 0. Box 1500

Richland, Washington 99352 
HNF-4034 Revision 0

TABLE OF CONTENTS

SECTION

PAGE

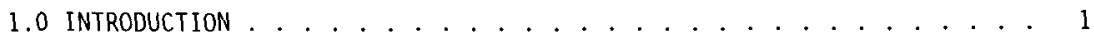

2.0 BACKGROUND . . . . . . . . . . . . . . . . . . . . . . . 1

2.1 Occurrence Report RL-PHMC-1998-0141 .......... 1

2.2 Process Test Plan: Phase I .............. 2

2.3 Process Control Plan .............. 2

3.0 OBJECTIVES AND CRITERIA. .................. 3

3.1 Objectives . . . . . . . . . . . . . . . 3

3.2 Process Criteria ................ . . 3

3.2.1 WRSS Process Control Criteria ........ 3

3.2.2 Sampling Control Criteria ......... 5

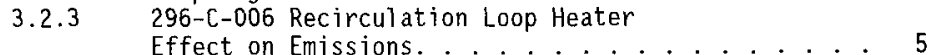

4.0 TEST DESCRIPTION . . . . . . . . . . . . . . . . 6

4.1 Process Test................. . . . 6

4.2 Process Test Parameters, Limits, and Recovery Actions . . . . 6

4.2.1 Fl ammable Gas Monitoring and Response . . . . . . 6

4.2.2 Temperature Monitoring and Response . . . . . . . . . 7

4.2.3 Liquid-Level and Leak Detection Monitoring and Response 8

4.2.4 Tank Pressure and Ventilation Monitoring and Response . 9

4.2.5 296-C-006 Ventilation System Stack

Flow Monitoring and Response ........... . 9

4.2.6 Standard Hydrogen Monitoring System Monitoring and Response ............ 10

4.2.7 Volatile Organic Compound Monitoring and Response: Tank 24l-C-106 ....... 10

4.2.8 Effluent Sampling: Tank 241-C-106 ....... 12

4.2.9 Volatile Organic Compound Monitoring and Response: Tank 241-AY-102 .......... 12

4.2.10 Volatile Organic Compound Monitoring and Response: 241-AZ-702 Ventilation system ........ 13

4.2.11 Effluent Sampling: 241-AZ-702 Ventilation system . . . 13

4.2.12 S7uice Stream Control . . . . . . . . . . . 14

4.2.13 296-C-006 Recirculation Loop Heater Effect on Emissions 14

4.3 Process Test Conditions. . . . . . . . . . . . 15

4.3.1 Process Test Pre-start and Continuous Conditions . . . 15

4.3.2 Process Test Duration Conditions.......... 16

4.3.3 Process Test Termination Conditions. . . . . . . . 17

5.0 TEST REQUIREMENTS. . . . . . . . . . . . . . . . . 18

5.1 Data Requirements and Test Documentation . . . . . . . . 18

5.2 Personne1 Requirements ............. 18 


\section{HNF-4034 Revision 0}

\section{TABLE OF CONTENTS (continued)}

SECTION

PAGE

6.0 SAFETY AND QUALITY ASSURANCE .................... . . 20

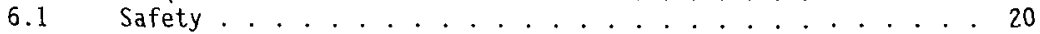

6.2 Quality Assurance. . . . . . . . . . . . . . . . . 20

7.0 ENVIRONMENTAL COMPLIANCE ...................... 21

8.0 OPERATIONAL SAFETY REQUIREMENTS AND OPERATING

SPECIFICATIONS DEVIATIONS. . . . . . . . . . . . . . . . . 21

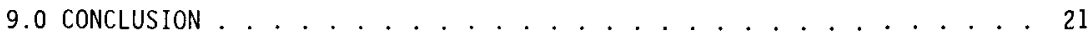

10.0 REFERENCES . . . . . . . . . . . . . . . . . . . 22

APPENDIX A: Plant Operating Procedures Applicable to WRSS Operations During

Process Test . . . . . . . . . . . . . . . . 25

APPENDIX B: HNF-IP-0842: WHC-IP-0842 Volume IV Section $4.7 \ldots \ldots . . . . .26$ 
HNF-4034 Revision 0

\subsection{INTRODUCTION}

Tank 241-C-106 is Hanford's only High Heat Watch List Single-She11 waste storage tank. It is highly desirable to eliminate the need for periodic cooling water additions required due to the high-heat generation of the sludge content.

The Waste Retrieval Sluicing System (WRSS) was installed under Project W-320 and provides the necessary equipment to safely retrieve and transfer Tank 241-C-106 waste to Double-She11 Tank 241-AY-102 for interim storage.

Operation of the WRSS will resolve a high profile safety issue and demonstrate enhanced sluicing technology.

\subsection{BACKGROUND}

2.1 RL-PHMC-1998-0141, Occurrence Report: 296-C-006 Stack Exceeded Volatile Organic Compound (VOC) Limit, November 19, 1998

Sluicing operations began at Tank 241-C-106 on Wednesday, November 18, 1998. The sluicing of 241-C-106 was not expected to generate organic emissions of any appreciable quantity. Following Process Memo \#2E98-018, WRSS - Guidance for Industrial Health Sampling, and Job Control System (JCS) work package 2E-98-1711, 241-C Perform VOC Measurements W-320 Exhaust Skid, baseline Volatile Organic Compound (VOC) readings were obtained, and VOC emissions were monitored using Industrial Hygiene and Safety (IH\&S) field instrumentation during active sluicing. Additionally, personal and area samples for organic and ammonia exposure analysis were collected and field screening was performed in the work area. Unexpectedly, the VOC readings from the 296-C-006 ventilation stack reached 450 ppmv, exceeding the established limit of 50 ppmv (reference DOE/RL-95-62, Nonradioactive Air Emissions Notice of Construction Project W-320, 241-C-106 Tank Sluicing, Revision 1).

Actions were taken to establish a respiratory protection zone in accordance with HNF-SD-WM-HSP-002, Tank Farm Health and Safety Plan. Limited stack and grab sampling was performed during the event by IH\&S technicians. The analysis of the samples were not conclusive of the constituents emitted from stack 296-C-006, although preliminary analytical results of the personal and area samples indicated no detectable ammonia or organic vapor concentrations.

During the sluicing evolution, employee health concerns were expressed, and the necessity of further stack emission controls identified. The need for exacting data of the emission constituents is necessary to establish administrative controls and/or to design adequate equipment to mitigate any chemical stack emissions. The final result is the protection of workers. 
HNF-4034 Revision 0

\subsection{Process Test Plan: WRSS Emissions Collection, Phase I}

HNF-3733, Process Test Plan: Waste Retrieval Sluicing System Emissions Collection, HNF-3732, Waste Retrieval Sluicing System Vapor Sampling and Analysis Plan for Evaluation of Organic Emissions, and the associated Process Test Procedure PTP-320-001, Process Test Procedure: Waste Retrieval Sluicing System Emissions Collection, were implemented on December 16, 1998 . The Process Test provided a basis for the controlled, safe acquisition of gaseous data during basic operation of the sluicing system. The data was to be analyzed to provide criteria for the design of equipment, or to determine the administrative controls necessary to safeguard workers.

The sluicing system was operated for approximately 64 minutes before the Process Test was procedurally terminated due to an alarming leak detector installed in the 241-C-O6C pit.

The source of the leak detector activation was determined to be a leak at the wall connection of the sluicer feed line. The Volatile Organic Compound (VOC) emissions level reached approximately 30 parts per million parts, volume (ppmv); the desired levels were 70 to 100 ppmv. Limited sample data taken during the Process Test was analyzed, but the need for further samples collected at higher waste agitation and VOC emission levels remains necessary.

\subsection{Tank 241-C-106 Waste Retrieval Sluicing System Process Control Plan}

HNF-SD-WM-PCP-013, Tank 241-C-106 Waste Retrieval Sluicing System Process Control Plan, coordinates the technical operating requirements (primary mass transfer, temperature, flammable gas) for the sluicing operation and provides overal1 technical guidance for the retrieval activity. This Process Test Plan utilizes HNF-SD-WM-PCP-013 in its entirety for the operation of the WRSS. It augments the Process Control Plan with the guidance necessary to obtain emission characterization data and quantify stack emissions, thus defining any necessary equipment modifications or process methods needed to mitigate chemical emissions and protect WRSS workers. 
HNF-4034 Revision 0

\subsection{PROCESS TEST OBJECTIVES AND CRITERIA}

\subsection{Objectives}

The main objective of this Process Test is to safely obtain analytical data to be used to further define existing hazards associated with the 296-C-006 ventilation system stack emissions during active sluicing of Tank 241-C-106. This data will be obtained by instituting a controlled sluice system operation approach that will increase gaseous emissions at a graduated rate (based on active sluicing experience and results from Phase I of the Process Test). Gaseous emissions shall also be monitored, and if specific limits of VOC are reached samples may be collected and analyzed for 241-AY-102 and the 241-AZ-702 ventilation system.

Al1 perceivable personnel precautions shall be considered, and implemented as practical. Only essential personnel with prescribed Personal Protective Equipment (PPE) for their role and location will be permitted to conduct the Process Test. Training will be verified as current. All test participants will attend a pre-job meeting to verify knowledge of the known hazards. The opportunity shall be given to voice concerns; resolutions of those concerns shall be addressed before the Process Test will commence.

Procedures for the sluicing evolution of the Process Test shall predicate that the plant is maintained in a safe configuration. HNF-SD-WM-PCP-013, Tank 241-C-106 Waste Retrieval Sluicing System Process Control P7an, establishes the controls necessary for typical sluice system operations. These controls are incorporated into the WRSS P1ant Operating Procedures and A1arm Response Procedures (reference Appendix A), and PTP-320-001, Process Test Procedure, Phase II: Waste Retrieval Sluicing System Emissions Collection. This Process Test Plan relies on HNF-SD-WM-PCP-013 as the basis for active operation of the sluicing system during the Process Test.

The controls necessary to conduct gas sampling as detailed in HNF-4030, Waste Retrieval Sluicing System Vapor Sampling and Analysis Plan for Evaluation of Organic Emissions, Process Test Phase II, are dictated by this Process Test Plan. These controls assemble the necessary testing methods with a graded sluicing approach in a safe manner to obtain the test objective.

\subsection{Process Criteria}

\subsubsection{WRSS Process Control Criteria}

The process criteria and specification 1 imits by which this test will be measured are those strictly associated with ensuring that Tank 241-c-106 and the WRSS is maintained in a safe configuration during the Process Test. For this Process Test, safety-related parameters include waste and dome space temperatures, leak detection, tank pressure, flammable gas generation, SHMS operability, and ventilation system operability -- 


\section{HNF-4034 Revision 0}

a11 of which are addressed by HNF-SD-WM-PCP-013, Tank 241-C-106 Waste Retrieval Sluicing System Process Control Plan.

The process criteria, specification limits, required monitoring frequencies, and reporting requirements for these safety-related parameters adhere to the requirements contained in authorization basis documentation, administrative controls, operating specification document requirements, and $\mathrm{Flammable} \mathrm{Gas} \mathrm{Advisory} \mathrm{Board} \mathrm{reports}$ applicable to Tank 241-C-106, 241-AY-102, and the 24l-AZ-702 ventilation system. These documents are listed below.

HNF-SD-WM-BI0-001, Tank Waste Remediation System Basis for Interim Operation

- WHC-IP-0954, Tank Farm Interim Operational Safety Requirements Comp 1 iance Implementation Plan

- OSD-T-151-00013, Operating Specifications for Single-She11 Waste Storage Tanks

- OSD-T-151-00030, Operating Specifications for Watch List Tanks

USQ \#TF-96-0433, Revision 1, Consolidation of Flammable Gas/Slurry Growth Unreviewed Safety Question Issues

HNF-SD-W320-TA-001, Revision 1, Assessment of Project W-320 Equipment for Compliance with Flammable Gas Controls Specified by East and West Tank Farms Standing Order 97-01

USQ \#TF-98-1248, Revision 1, 241-C-106, WRSS: Process Test Plan HNF-3733 and Process Test Procedure PTP-320-001

The Process Test sha11 cease in a controlled or emergent manner in the event that any of the process criteria are exceeded as described in section 4.2. The process criteria are:

4.2.1 Flammable Gas

4.2.2 Tank Temperature

4.2.3 Liquid-Leve 7 and Leak Detection

4.2.4 Tank Pressure and Ventilation System Operability

4.2.5 296-C-006 Ventilation System Stack Flow Monitoring and Response 4.2.6 Standard Hydrogen Monitoring System Operability 
HNF-4034 Revision 0

4.2.7 Volatile Organic Compound Monitoring: Tank 241-C-106

4.2.8 Effluent Sampling: Tank 24l-C-106

4.2.9 Volatile Organic Compound Monitoring: Tank 241-AY-102

4.2.10 Volatile Organic Compound Monitoring: 241-AZ-702

4.2.11 Effluent Sampling: 24l-AZ-702 ventilation system

4.2.12 STuice Stream Control

4.2.13 296-C-006 Recirculation Loop Heater Effect on Emissions

The Plant Operating Procedures which implement requirements for WRSS Operations are listed in Appendix $A$. In addition, there are numerous administrative Process Test conditions and shutdown criteria that shall be implemented and adhered to procedurally. These are detailed in Section 4.3.

It should be noted that administrative controls have been implemented into the appropriate operating procedures to ensure water slugging is not induced on the sluicer and its associated piping. It has been postulated that water slugging may have contributed to the transfer jumper leak at the 24l-C-06C pit during Phase I of the Process Test.

\subsubsection{Sampling Control Criteria}

Sampling shall be conducted in accordance with HNF-4030, Waste Retrieval Sluicing System Vapor Sampling and Analysis Plan for Evaluation of Organic Emissions, Process Test Phase II. Job Control System (JCS) work packages safely implement the sampling requirements. The JCS work packages are referenced in PTP-320-001, Process Test Procedure, Phase II: Waste Retrieval S7uicing System Emissions Collection.

\subsubsection{6-C-006 Recirculation Loop Heater Effect on Emissions}

The effect of the recirculation loop process air heater on the 296-C-006 ventilation system stack emissions may be evaluated during the Process Test. Testing shall include de-energizing the heater for a period of time during the final portion of the test and collecting additional samples when the tank and exhaust system have reached equilibrium. The data will be used to determine if heating the air stream causes volatilization of organic carbons or ammonia. 
HNF-4034 Revision 0

\subsection{TEST DESCRIPTION}

\subsection{Process Test}

Samples of effluent gas generated in Tank 241-C-106 during controlled and limited sluicing operations will be collected for analysis. The gasses will be analyzed for numerous analytes that may impose a health hazard to workers.

To facilitate this sampling event and to ensure that representative samples of the tank ventilation system's emissions are obtained, PTP-320-001, Process Test Procedure, Phase II: Waste Retrieval Sluicing System Emissions collection, will implement the requirements of the Sample and Analysis Plan and this Process Test Plan. Controlled operation of the sluicing system shall be conducted using established procedures. Operation of the sluicer will be basic and controlled in order to 1 imit the gaseous emissions. Plant Operating Procedure T0-320-005, Waste Retrieval s7uicing System Startup and Process Control, will be utilized during the Process Test to establish the start up configuration and dictate transfer parameters. Plant Operating Procedure T0-320-006, TK-241-C-106 Waste Retrieva7 Sluicing System Sluicing Operations, will be used to control pump and sluicer operations during the process test. A11 active support procedures and Alarm Response Procedures pertinent to WRSS operations will apply. (See Appendix A for a listing of applicable procedures.)

\subsection{Process Test Parameters, Limits, and Recovery Actions}

The sections below outline the desired values and permissible ranges for the process and operating variables that will be relied upon for process control, and a description of corrective or shutdown actions to be taken if deviating from permissible ranges. In the event that any one of the following parameters are exceeded, resulting in the stoppage of the Process Test, approval from the Joint Test Review Group must be obtained prior to recommencing the test. Required stoppage of the test signifies the appropriate shutdown (controlled, or graded emergency approach) of sluicing operations, and the application of administrative controls to the appropriate ventilation systems as necessary to ensure the protection of workers. Site Emergency Procedures will be implemented by the Shift Manager as necessary.

\subsubsection{Flammable Gas Monitoring And Response}

\subsubsection{Flammable Gas Criteria}

HNF-SD-WM-PCP-013, Tank 241-C-106 Waste Retrieval S7uicing System Process control Plan, fully establishes the flammable gas criteria and controls for sluicing, and these same criteria apply to this Process Test. These criteria and controls are implemented via appropriate WRSS Plant Operating Procedures and Alarm Response Procedures (reference Appendix A), and Job Control System (JCS) work packages outlined in 


\section{HNF-4034 Revision 0}

PTP-320-001, Process Test Procedure, Phase II: Waste Retrieval Sluicing System Emissions Collection, which will be utilized during the Process

Test.

Flammable gas data was collected and analyzed during the previous Process Test. Although an increase in flammable gas was noted, the concentrations remained relatively small. (Reference Correspondence No. 74B50-99-012, J. A. Lechelt.)

\subsubsection{Monitoring Frequencies}

Flammable gas concentrations will be continuously monitored via the SHMS located on Tanks 241-C-106 and 241-AY-102.

\subsubsection{Response and Recovery}

In the event that flammable gas criteria are exceeded, the Process Test will be stopped per T0-320-006, TK-241-C-106 Waste Retrieval Sluicing System S7uicing operations.

\subsubsection{Temperature Monitoring and Response}

\subsubsection{Tank Temperature Criteria}

HNF-SD-WM-PCP-013, Tank 241-C-106 Waste Retrieval S7uicing System Process Control Plan, addresses authorization basis requirements for temperature control and establishes the tank temperature criteria applicable to this Process Test. Tanks 241-C-106 and 241-AY-102 waste and dome space temperatures are monitored and recorded continuously. The data is used to determine if waste temperatures are within the established baseline. Waste temperature in Tank 241-C-106 is a key parameter for safety control.

On November 10, 1998, temperatures in 241-C-106 began to increase, and continued to rise for the next 2 months. The abnormality was an issue for the 241-C-106 Technical Review Group(TRG); analysis determined acceptable sub-cooling remains in the tank to continue sluicing operations (reference HNF-3941, Project W-320 Evaluation of Riser 14 Temperature Response, Ogden, D. M., Sathyanarayana, K., Cramer, E. R. 1999).

\subsubsection{Monitoring Frequencies}

Tank 24l-C-106 sludge temperature and dome space temperature readings are recorded continuously by TMACS. Tank 241-AY-102 waste and dome space temperature readings are recorded continuously by the WRSS DAS. The TMACS and DAS alarm on high temperatures. 
HNF-4034 Revision 0

Significant temperature transients for Tanks 241-C-106 and 241-AY-102 are not expected during the Process Tesi.

\subsubsection{Response and Recovery}

In the event that any temperature criteria referenced above in Section 4.2.2.1 is approached, the Process Test will be terminated using a controlled shutdown mode, and, at the discretion of the Test Director, the sampling will continue following the approved Job Control System (JCS) work packages outlined in PTP-320-001, Process Test Procedure, Phase II: Waste Retrieval Sluicing System Emissions Collection.

The temperature anomaly shall be evaluated by the 241-C-106 TRG, and subsequent actions and requirements shall be defined and implemented before the Process Test may resume.

\subsubsection{Liquid-Level and Leak Detection Monitoring and Response}

\subsubsection{Waste Tank Leak-Detection Criteria}

Leak detection criteria is well established in HNF-SD-WM-PCP-013, Tank 241-C-106 Waste Retrieval S7uicing System Process Control Plan, for sluicing and fully applies to this Process Test.

\subsubsection{Monitoring Frequencies}

Transfer pit and line leak detection, mass balance calculations, and 241-AY-102 annulus leak detection are methods relied upon for leak detection during sluicing. Procedure T0-320-006, TK-241-C-106 Waste Retrieval Sluicing System Sluicing Operations, employs the associated leak detection and interlock systems which operate continuously. Periodic mass balances are established by Plant Operating Procedure T0-320-003, Waste Retrieval Sluicing System Material Balance. At the conclusion of the Process Test a mass balance will be performed by Process Engineering to establish final waste volumes.

\subsubsection{Response and Recovery}

Abnormal changes in tank liquid levels, mass balance discrepancies, and leak detection alarms shall preclude continuance of the Process Test. The sampling plan as established in Job Control System (JCS) work packages will continue at the direction of the Test Director, with Shift Manager concurrence. 


\section{HNF-4034 Revision 0}

\subsubsection{Tank Pressure and Ventilation System Monitoring and Response}

\subsubsection{Tank Pressure and Ventilation Criteria}

Tank pressure monitoring for Tank 241-C-106 is performed mainly to monitor the performance of the ventilation system. Plant Operating Procedure T0-320-009, Operate WRSS 296-C-006 HVAC System, provides direction and controls for pressure in 241-C-106.

At 241-AY-102, tank pressure is monitored and alarms provide notification of established abnormal pressures. These readings are monitored and recorded by the DAS for 241-C-106, and by the 241-AZ-702 Micon for 241-AY-102.

Specific operating parameters for Tank 241-C-106 are also 1 isted in OSD-T-151-00013, Operating Specifications for Single-She11 Waste Storage Tanks. These parameters are implemented by T0-320-009, Operate WRSS 296-C-006 HVAC System.

\subsubsection{Monitoring Frequencies}

Pressure monitoring and alarms are continuously operable during the Process Test. ARP-T-331-00003, Respond to Alarms at MO-211 WRSS Control Room, and ARP-T-331-00006, Respond to Alarms at Process Contro7 Building, give appropriate responses to pressure and ventilation alarm states. It should be noted that the dome space pressure at $241-C-106$ is independently monitored continuously by TMACS.

\subsubsection{Response and Recovery}

In the event that any tank pressure criteria referenced in Section 4.2.4.1 is exceeded, standard response and recovery actions shall be implemented per the applicable procedures. The Process Test may be terminated or continued at the direction of the Test Director.

\subsubsection{6-C-006 Ventilation System Stack Flow Monitoring and Response}

For purposes of this Process Test, stack flow rates for the 296-C-006 ventilation system shall be recorded.

\subsubsection{Stack Flow Criteria}

The control limit for the 296-C-006 ventilation system stack flow is 360 $\mathrm{cfm}$. (Reference D0E/RL-95-62, Nonradioactive Air Emissions Notice of Construction Project W-320, 241-C-106 Tank Sluicing, Revision 1.) Plant Operating Procedure T0-320-009, Operate WRSS 296-C-006 HVAC System, provides direction and controls for maintaining this limit. There is no additional criteria established by this Process Test. 


\section{HNF-4034 Revision 0}

\subsubsection{Monitoring Frequency}

Stack flow rates sha 11 be recorded at least every 10 minutes when sampling is being performed at 296-C-006 as outlined in PTP-320-001, Process Test Procedure, Phase II: Waste Retrieval S7uicing System Emissions Collection.

\subsubsection{Response and Recovery}

T0-320-009, Operate WRSS 296-C-006 HVAC System, provides the appropriate response and recovery actions for exceeded stack flow rate. The Process Test may be terminated or continued at the direction of the Test Director.

\subsubsection{Standard Hydrogen Monitoring System Monitoring and Response}

\subsubsection{Standard Hydrogen Monitoring System Criteria}

The SHMS for Tanks 241-C-106 and 241-AY-102 shal1 be operable for the duration of the Process Test. If the SHMS becomes inoperable during the Process Test, WRSS operations shall be curtailed until the SHMS is restored. HNF-SD-WM-PCP-013, Tank 241-C-106 Waste Retrieval Sluicing System Process Control Plan, addresses authorization basis requirements for hydrogen/flammable gas control and establishes the criteria applicable to this Process Test.

\subsubsection{Monitoring Frequency}

The SHMS at Tanks 241-C-106 and 241-AY-102 shall be verified to be operable and shall operate during the Process Test.

\subsubsection{Response and Recovery}

In the event the SHMS becomes inoperable and cannot be restarted, the WRSS shall enter a controlled shutdown per T0-320-006, TK-241-C-106 Waste Retrieval sluicing System Sluicing operations, and the controlled sampling scheme outlined by the Job Control System (JCS) Work Packages may continue at the direction of the Test Director. 


\section{HNF-4034 Revision 0}

\subsubsection{Volatile Organic Compound Monitoring and Response: Tank 241-C-106}

Volatile Organic Compound (VOC) shall be monitored and sampled to fully characterize these emissions and obtain data for use in mitigating safety concerns.

\subsubsection{Volatile Organic Compound Criteria: Tank 241-C-106}

The VOC should be maintained between 300 ppmv and 400 ppmv to obtain the desired samples.

This is accomplished by establishing Process Test Control Limit (PCL) \#1, at 300 ppmv (3-minute average) as measured at the 296-C-006 stack in which the waste agitation will be controlled. PCL \#2 is 400 ppmv (3minute average) at the 296-C-006 stack. If PCL \#2 is reached, a controlled evacuation of all non-essential personnel from 241-C Tank Farm shall be made. In addition, an Emergency Shutdown per PTP-320-001, Process Test Procedure, Phase II: Waste Retrieval Sluicing System Emissions Collection, of the WRSS shall be performed.

A Process Test Emergency Limit is established at 500 ppmv (3-minute average) measured at the 296-C-006 ventilation stack. Should the Emergency Limit be reached, an Emergency Shutdown per PTP-320-001, Process Test Procedure, Phase II: Waste Retrieval Sluicing System Emissions Collection, of the WRSS shall be performed and all personnel at 241-C Tank Farm and those involved with the test shall evacuate. Emergency Response Procedures will be implemented by the Shift Manager as necessary.

The approved Washington Department of Ecology test limit for VOC is 500 ppmv (60-minute average), (reference Meeting Minutes, Request for Ecology Concurrence on draft Strategy/Path Forward to Address Concerns Regarding Organic Emissions from C-l06 Sluicing Activities, K. A. Peterson, December 3, 1998).

An additional limit for the Process Test is 24 hours of total testing divided between two or more batches. Phase I consumed approximately 4 hours, leaving 20 hours remaining (reference Meeting Minutes, Request for Ecology Concurrence on draft Strategy/Path Forward to Address Concerns Regarding Organic Emissions from C-106 Sluicing Activities, K. A. Peterson, December 3, 1998).

During Process Test Phase II, the sluicing duration will be 1 imited to 9 hours to comply with process control limits for mass transfer (reference HNF-SD-WM-PCP-013, Tank 241-C-106 Waste Retrieval Sluicing System Process Control Plan). 
HNF-4034 Revision 0

\subsubsection{Monitoring Frequency: Tank 241-C-106}

Monitoring for VOC at the 296-C-006 stack shall be continuous when the 24l-AY-102 submersible pump is operating, and periodic during the process Test when the pumps are shutdown. The periodicity is outlined in procedures referenced in PTP-320-001, Process Test Procedure, Phase II: Waste Retrieval Sluicing System Emissions Collection. Continuous monitoring is defined as a manned, active monitoring instrument with, if available, an alarm set point of 400 ppmv. Calibration/instrument checks may interrupt the continuous monitoring for short durations.

\subsubsection{Response and Recovery: Tank 241-C-106}

If the VOC exceeds 400 ppmv, the WRSS shall enter a Emergency Shutdown per PTP-320-001, Process Test Procedure, Phase II: Waste Retrieval Sluicing System Emissions Collection. All non-essential personnel shall evacuate. If the VOC returns to below 400 ppmv, the Process Test may resume. Should VOC reach 500 ppmv VOC, the WRSS shall enter an

Emergency Shutdown per PTP-320-001, and a complete evacuation of all personnel shall be made. Decisions regarding implementation of Take Cover Procedures will be made by the Shift Manager.

\subsubsection{Effluent Sampling: Tank 241-C-106}

\subsubsection{Effluent Sampling Criteria: Tank 241-C-106}

Sampling shall be performed at the 296-C-005 stack in accordance with HNF-4030, Waste Retrieval S7uicing System Vapor Sampling and Analysis Plan for Evaluation of Organic Emissions, Process Test Phase II, and via Job Control System (JCS) work packages outlined in PTP-320-001, Process Test Procedure, Phase II: Waste Retrieval Sluicing System Emissions Collection, under the direction of the Test Director.

\subsubsection{Volatile Organic Compound Monitoring: Tank 241-AY-102}

For the purposes of this test, VOC may be monitored at the Tank 241-AY-102 dome space in accordance with Industrial Health and Safety Monitoring P1ans, if deemed necessary.

\subsubsection{Volatile Organic Compound Criteria: Tank 241-AY-102}

There is no criteria for measuring VOC at the dome space of 241-AY-102.

\subsubsection{Monitoring Frequency: Tank 241-AY-102}

Monitoring frequency is determined by Industrial Health and Safety Monitoring Plans, at the direction of the Test Director, if deemed necessary. 


$$
\text { HNF-4034 Revision } 0
$$

\subsubsection{Response and Recovery: Tank 241-AY-102}

There is no required response or recovery for VOC in the dome space of 241-AY-102.

\subsubsection{Volatile Organic Compound Monitoring and Response: 241-AZ-702}

VOC shall be monitored at the 24l-AZ-702 ventilation system for worker protection.

\subsubsection{Volatile Organic Compound Criteria: 241-AZ-702}

Maximum VOC allowed at 24l-AZ-702 ventilation stack is 50 ppmv (reference \#NOC-94-07, Notice of Construction Permit for Nonradioactive Air Emissions from the $A Y$ and $A Z$ Tank Farms Ventilation Upgrades). The Process Test Control Level is 50 ppmv, 3-minute average.

\subsubsection{Monitoring Frequency: 241-AZ-702}

Monitoring for $V O C$ at the 241-AZ-702 ventilation system shall be continuous when the 241-C-106 booster pump and/or submersible pump is operating, and periodic during the Process Test when the pumps are shutdown. The periodicity is outlined in the applicable Job Control system (JCS) Work Packages (reference PTP-320-001, Process Test Procedure, Phase II: Waste Retrieval Sluicing System Emissions Collection).

\subsubsection{Response and Recovery: 241-AZ-702}

If the criteria stated in 4.2.10.1 occurs at the 241-AZ-702 ventilation system, an Emergency Shutdown sha11 commence per PTP-320-001, Process Test Procedure, Phase II: Waste Retrieval Sluicing System Emissions Collection. The Shift Manager shall institute 241-AZ-702 specific procedures and make notifications as necessary.

Sampling may continue at the 296-C-006 stack at the direction of the Test Director.

It is anticipated that the controls implemented at 241-C-106 wi17 maintain 241-AZ-702 stack emissions below the 50 ppmv 1 evel.

\subsubsection{Effluent Sampling: 241-AZ-702 Ventilation System}

\subsubsection{Effluent Sampling Criteria: 241-AZ-702}

Sampling of the 241-AZ-702 ventilation stack may be performed per HNF4030, Waste Retrieval Sluicing System Vapor Sampling and Analysis Plan for Evaluation of Organic Emissions, Process Test Phase II, and via Job 
HNF-4034 Revision 0

Control System (JCS) work packages outlined in PTP-320-001, Process Test Procedure, Phase II: Waste Retrieval Sluicing System Emissions collection.

\subsubsection{Sluice Stream Control}

The sluice stream at $241-C-106$ shall be controlled in a manner that attempts to regulate the $V O C$ emissions. Flow rates, impact point, tilt and pan angle, and sweep path will be manipulated to produce a controlled release of VOC that can be measured and sampled at the 296-C-006 ventilation stack. PTP-320-001, Process Test Procedure, Phase II: Waste Retrieval Sluicing System Emissions Collection, establishes the process method.

\subsubsection{6-C-006 Recirculation Loop Heater Effect on Emissions}

The volatilization effect of the electric heaters in the recirculation loop of the 296-C-006 ventilation system may be tested by shutting off the heaters while continuing to operate the WRSS sluice pumps for approximately 2 hours towards the end of the Process Test. PTP-320-001, Process Test Procedure, Phase II: Waste Retrieval Sluicing System Emissions Collection, establishes the process method. There are no additional 7 imits or recovery actions involved with this activity. Note - This portion of the test is optional, to be performed at the discretion of the Test Director. 
HNF-4034 Revision 0

\subsection{Process Test Conditions}

This section summarizes the conditions required for starting the Process Test, the conditions required for maintaining the Process Test, and the conditions that will result in a termination of the Process Test.

\subsubsection{Process Test Pre-start and Continuous Conditions}

The following conditions must be met throughout the duration of the Process Test:

- Double-Shell Tank Farms Shift Manager shall be notified prior to starting the Process Test, and prior to the starting of each WRSS pump.

- Health Physics Technicians (HPT) shall provide continuous HPT coverage during active WRSS operations, and as needed when setting up sampling equipment.

- Environmental Operations Compliance Manager or delegate shall be notified prior to the planned Process Test and in the event that any associated exhaust system is shutdown or re-started, to ensure compliance with Washington Department of Ecology notification requirements.

- Operable thermocouples on the thermocouple trees located in Risers \#8 and \#14 must be operational for temperature monitoring of both the sludge and dome space in Tank 24l-C-106 per HNF-SD-WM-PCP-013, Tank 241-C-106 Waste Retrieval Sluicing System Process Control Plan.

- SHMS associated with Tanks 241-C-106 and 241-AY-102 shall be operational and remain operating for the duration of the Process Test.

- Access to the 241-C Tank Farm area and support buildings (i.e. M0-21l and 241-C Tank Farm change trailers) shall be limited to essential personnel as established by WRSS Management. Barricaded access points shall be established at all access roads and perimeter roads. No vehicular traffic may exist within the fenced area of 241-C Tank Farm during the Process Test without the approval of the Test Director.

- Communications shall be made to inform personnel of progressive activities during the Process Test. Other required communications shall include an all employee site message, announcements at $200 \mathrm{E}$ tailgate meetings, and $\mathrm{PAX} / \mathrm{radio}$ announcements. All essential personnel shall have continuous access to 2 -way radios.

- Wind socks shall be available to identify wind direction. 
- Prior to starting the 241-AY-102 booster pump, contact the Hanford Meteorological Station and obtain a 8-hour forecast of wind direction, wind speed, and atmospheric stability. WRSS Management will determine whether to proceed with testing based on the forecast.

- IH\&S shall evaluate and establish respiratory protection zones in accordance with HNF-SD-WM-HSP-002, Tank Farm Health and Safety Plan.

- If prevailing winds are directional from the 296-C-006 stack toward M0-211, participants at M0-211 sha11 remain indoors and building ventilation systems shall be turned off.

- Ensure responsible personnel identified in the test procedure are trained and certified and cognizant of the equipment, hazards, controls, administrative control zones, and usage of Personal Protective Equipment (PPE) associated with the Process Test.

\subsubsection{Process Test Duration Conditions}

Provided the Process Test is not terminated, the Process Test shall proceed according to the sampling plan HNF-4030, Waste Retrieval S7uicing System Vapor Sampling and Analysis Plan for Evaluation of Organic Emissions, Process Test Phase II, under the specific direction of the associated Job Control System (JCS) work packages. (Reference in PTP-320-001, Process Test Procedure, Phase II: Waste Retrieval Sluicing System Emissions Collection.)

Under agreement with the Washington Department of Ecology, the acceptable duration for process testing is 24 consecutive hours (reference Meeting Minutes, Request for Ecology Concurrence on draft Strategy/Path Forward to Address Concerns Regarding Organic Emissions from $\mathrm{C}-106$ Sluicing Activities, K. A. Peterson, December 3, 1998). Approximately 4 hours of testing have elapsed during Phase I of the Process Test. Phase II is expected to take less than 9 hours. The siuicer operation for Process Test Phase II will be limited to 9 hours or less. 
HNF-4034 Revision 0

\subsubsection{Process Test Termination Conditions}

\subsubsection{Routine Termination Condition}

WRSS activities shall be terminated (routine shutdown) and a controlled sampling plan continued if the following condition occurs:

- The shutdown conditions specified by T0-320-006 or associated PTant Operating Procedure or Alarm Response Procedures are experienced

\subsubsection{Emergency Shutdown and Reduced Personnel Condition}

WRSS activities shall be terminated (Emergency Shutdown) and an evacuation made of non-essential personnel at 241-C Tank Farm if the following condition occurs:

- The VOC concentration for Tank 241-C-106 ventilation stack reaches 400 ppmv, 3-minute average

\subsubsection{Emergency Shutdown and Evacuate Condition}

WRSS activities shall be terminated (Emergency Shutdown) and an evacuation made of a 11 personnel at 241-C Tank Farm if the following condition occurs:

- The VOC concentration for Tank 241-C-106 ventilation stack reaches 500 ppmv, 3-minute average

\subsubsection{Emergency Shutdown Condition at 241-AZ-702}

WRSS activities shall be terminated (Emergency Shutdown) if the following condition occurs:

- The $V O C$ concentration at the 241-AZ-702 ventilation stack reaches 50 ppmv, 3-minute average 
HNF-4034 Revision 0

\subsection{TEST REQUIREMENTS}

\subsection{Data Requirements and Test Documentation}

5.1.1 Testing shall be controlled in accordance with HNF-IP-0842, TWRS Administrative Procedure, Volume IV, Engineering, Section 4.7, Process Tests. Data shall be obtained during the testing as identified in Section 4.0 of this Process Test Plan. At the completion of this test, the data sheets and/or their information will be included in the final test evaluation report.

5.1.2 HNF-4030, Waste Retrieval S7uicing System Vapor Sampling and Analysis Plan for Evaluation of Organic Emissions, Process Test Phase II, dictates the methodology for data collection for this Process Test.

\subsection{Personnel Requirements}

- A Certified Operations Engineer (OE) will act as the Test Director and be available for the duration of Process Test. The Test Director is responsible for supervising all field activities, ensuring and documenting that prerequisite conditions are met, and coordinating activities among the various organizations.

- The Cognizant Engineer and/or Design Authority is responsible for providing technical assistance to operations management and the Test Director throughout the Process Test.

- A Double-Shell Tank Farms certified "routines" operator is responsible for operation of the Tank 241-C-106 SHMS " $C$ " unit and sample gas conditioner during the Process Test.

- Industrial Hygiene Technicians are responsible for performing preestablished stack, area, and personal sampling during the Process Test as described in the Job Control System (JCS) Work Packages. Additional sampling will be performed as directed by the Industrial Hygienist.

- Industrial Hygienists are responsible for providing Industrial Hygiene support to Waste Retrieval Sluicing System operations as identified in HNF-SD-WM-HSP-002, Tank Farm Health and Safety Plan.

- Health Physics Technicians shall be available for the duration of the Process Test and are responsible for radiological surveys and recommending radiological controls and actions to the Test Director during the performance of this procedure. Continuous coverage is required during active sluicing. 


\section{HNF-4034 Revision 0}

- Certified Characterization Project Operations personnel are responsible for obtaining the SUMMA canister samples and particulate air samples at the 241-AZ-702 stack in accordance with approved JCS Work Packages.

- Special Analytical Studies personnel are responsible for obtaining all other samples in accordance with approved JCS Work Packages. 


\section{HNF-4034 Revision 0}

\subsection{SAFETY AND QUALITY ASSURANCE}

\subsection{Safety}

This test shall be performed in accordance with but not limited to all applicable DOE orders as designated within the following Hanford Facility documents and will be delineated in PTP-320-001, Process Test Procedure, Phase II: Waste Retrieval S7uicing System Emissions Collection:

- HNF-SD-WM-HSP-002, Tank Farm Health and Safety Plan

- HSRCM-1, Hanford Site Radiological Control Manual

This Process Test requires a Special Radiological Work Permit (RWP).

Current respiratory protection and radiological requirements as set forth by the following organizations in WRSS Plant Operating Procedures and $A 1$ arm Response Procedures (reference Appendix A), PTP-320-001, Process Test Procedure, Phase II: Waste Retrieval Sluicing System Emissions Collection, and Job Control System (JCS) work packages shall also be observed by:

- Industrial Hygiene and Safety

- Health Physics Department

- Operations Management

\subsection{Quality Assurance}

Quality Assurance requirements exist for this Process Test and are identified in HNF-4030, Waste Retrieval Sluicing System Vapor Sampling and Analysis Plan for Evaluation of Organic Emissions, Process Test Phase II, for sampling and analysis requirements. These requirements are instituted into the applicable JCS work packages associated with this Process Test. (Reference PTP-320-001, Process Test Procedure, Phase II: Waste Retrieval Sluicing System Emissions Collection.) 
HNF-4034 Revision 0

\subsection{ENVIRONMENTAL COMPLIANCE}

- Environmental Operations Compliance must be notified in the event of a leak during transfer operations per the Environmental Compliance On-Call List. Environmental Operations Compliance will make the appropriate leak or release notification to Fluor Daniel Environmental Protection.

- To meet the requirements of Washington Administrative Code (WAC), Chapter 173-303, Dangerous Waste Regulations, spilled or leaked waste must be removed from transfer piping secondary containment, with the exception of catch tanks, within twenty-four hours of detection.

\subsection{OPERATIONAL SAFETY REQUIREMENTS AND OPERATING SPECIFICATIONS DEVIATIONS}

Most of the Process Test parameters and process criteria identified for this Process Test are more conservative than the limits and controls identified for these parameters in authorization basis documentation including applicable operational safety requirement and operations specification documents (OSRs and 0 SDs respectiveTy). No deviations from TSR, OSR or OSD limits are planned for this Process Test.

\subsection{CONCLUSION}

Tank 241-C-106 is unique among the Hanford Site Single-Shel1 Tanks, requiring special attention due to its high heat output. Thus, Process Tests conducted within this tank deserve strong management attention to ensure test personne? and procedures reflect a special discipline and caution to safeguard personnel and the environment. 
HNF-4034 Revision 0

\subsection{REFERENCES}

Alstad, A. T., 1993a, Riser Configuration Document for Single-She11 Tanks, WHC-SD-RE-TI-053, Rev. 9, Westinghouse Hanford Company, Richland, Washington.

Alstad, A. T., 1993b, Process Test Plan: Tank 241-C-106, WHC-SD-WM-PTP-026, Rev. 0, Westinghouse Hanford Company, Ricland, Washington.

Bailey, J. W. 1993, Tank 241-C-106 Leak Study, WHC-SD-WM-ES-218, Westinghouse Hanford Company, Richland, Washington.

Bander, T. J., 1993a, Revised Thermal History of Tank 241-C-106, WHC-SD-WM-ER-200, Rev. 0, Westinghouse Hanford Company, Richland, Washington.

Bander, T. J., 1993b, Thermal History of Tank 241-C-106, WHC-SD-WM-ER-161, Rev. 0, Westinghouse Hanford Company, Richland, Washington.

Bander, T. J., 1995, Tank 241-C-106 Process Test Report, WHC-SD-WM-ER-427, Rev. 0, Westinghouse Hanford Company, Richland, Washington.

Bellomy, J. R., 1998, 241-C-106, WRSS: Process Test Plan HNF-3733 and Process Test Procedure PTP-320-001, USQ TF-98-1248, Rev. 0, Lockheed Martin Hanford Company, Richland, Washington.

Bragg, D. A., 1995, 24l-C-105 Process Test Evaluation Report, WHC-SD-WM-PTR-013, Westinghouse Hanford Company, Richland, Washington.

Carothers, K. G., 1998, Tank 241-C-106 Waste Retrieval Sluicing System Process Control Plan, HNF-SD-WM-PCP-013, Rev. 1, Lockheed Martin Hanford Company, Richland, Washington.

Cash, R. J., 1997, Letter of Instruction for Sampling and Analysis of Tank 241-C-106 Vapor Grab Samples, (External memorandum LMHC-9752490 to L. M. Calderon, W. J. Kennedy, and M. W. Goheen, Apri1 16, 1997), Lockheed Martin Hanford Company, Richland, Washington.

Crumme1, G. M., February 17, 1999, Meeting Minutes, "Request to Re-obtain Health Concurence on the Temporary Installation of Multiple Vapor Sampling Probes for use to Address Concerns Regarding Organuc Emissions from $\mathrm{C}-106$ Sluicing Activities."

DOE/RL-95-62, Nonradioactive Air Emissions Notice of Construction project W320, 241-C-106 Tank Sluicing, Revision 1.

Fowler, K. D., 1995, Data Qual ity Objectives for Tank Farms Waste Compatibi ity Program, WHC-SD-WM-DQ0-001, Rev. 1, Westinghouse Hanford Company, Richland, Washington. 


\section{HNF-4034 Revision 0}

\subsection{REFERENCES (Continued)}

Fryer, B. C. and M. J. Thurgood, 1995, Revised Tank Heat Load Estimate for Tank 241-C-106 Based on GOTH Analys is of Process Test, JMI-9503-04, John Marvin, Inc., Richland, Washington.

Hand, F. R. and Rensink, G. E., 1996, Action Plan for Response to Excessive Temperatures in Hanford Site High-Heat Waste Tank 241-C-106, WHC-EP-0473, Rev. 3, Westinghouse Hanford Company, Richland, Washington.

Hanion, B. M., 1997, Waste Tank Summary Report for Month Ending January 31 , 1997, HNF-EP-0182-106, Lockheed Mart in Hanford Company, Richland, Washington.

HNF-IP-0842: WHC-IP-0842, TWRS Administrative Procedure, Volume IV, "Engineering," Section 4.7, "Process Tests," Westinghouse Hanford Company, Richland, Washington.

HNF-SD-WM-HSP-002, Tank Farm HeaIth and Safety Plan

Jimenez, R. F., 1991, Thermal Analysis of Tanks 241-C-105, 106 Using TAP-A as the Thermals Analys is Code, WHC-SD-WM-ER-075, Rev. 0, Westinghouse Hanford Company, Richland, Washington.

Jones, J. M., 1997, Process Test PTan: Tank 241-C-106 296-P-16 Exhauster Outage, WHC-SD-WM-PTP-030, Rev. 0, Lockheed Martin Hanford Company, Richland.

Jones, J. M., 1997, Process Test: Tank 241-C-106 296-P-16 Exhauster Outage, 0TP-060-002, Rev. 0, Lockheed Martin Hanford Company, Richland.

Lechelt, J. A., Correspondence No. 74B50-99-012, Tanks 241-C-106 and 241-AY102 Flammable Gas Releases Associated with Sluice Batch 1.1.1 on November 18, 1998.

Matheson, J. D., 1996, Hydrogen Gas Analysis Resu1ts For SUMMA Canister and Whitey Cylinder Samples Collected From The Exhaust Port of Single Shell Tank 241-C-106 On March 16, 1996, (PNNL Letter 9601227 WHC, to R. J. Cash, May 9), Pacific Northwest Nationa1 Laboratory, Richland, Washington.

Miller, P. C., November 12, 1998, Meeting Minutes, "Meeting to Clarify $W-320$ NOC Conditions for the Ventilation/Recirc System during Sluicing Activities."

Ogden, D. M., Sathyanarayana, K., Cramer, E. R., HNF-3941, Project $W-320$ Evaluation of Riser 14 Temperature Response, 1999.

Peterson, K. A., December 3, 1998, Meeting Minutes, Request for Ecology Concurrence on draft Strategy/Path For'ward to Address Concerns Regarding Organic Emissions from $\mathrm{C}-105$ Sluicing Activities.

RL-PHMC-1998-0141, November 19, 1998, Occurrence Report: 296-C-006 Stack Exceeded Volatile Organic Compound (VOC) Limit. 


\section{HNF-4034 Revision 0}

\subsection{REFERENCES (Continued)}

Rodenhizer, D. G., 1987, Hanford Waste Tank Sluicing History, WHC-SD-WM-TI-302, Rev. 0., Westinghouse Hanford Company, Richland Washington.

Schreiber, R. D., 1996, Tank Characterization Report for Single-Shell Tank 241-C-106, WHC-SD-WM-ER-615, Rev. 0, Westinghouse Hanford Company, Rich1 and Washington.

Smith, S. J. 1994, Senior Management Review Team Report on Process Testing of Waste Tank 241-C-106, (Internal Memorandum 10400-94-040 to W. T. Alumka1, August 24), Westinghouse Hanford Company, Richland, Washington.

Vitro, 1986, Piping Waste Tank Isolation TK 241-C-106, Drawing No. H-2-73346, Rev. 2, Vitro Engineering Corporation, Richland, Washington.

Weiss, R. L., 1991, Data Transmitta1 Package for 241-C-106, Waste Tank Characterization, WHC-SD-RE-TI-205, Rev. 0, Westinghouse Hanford Company, Richland, Washington.

WHC, 1996a, Operating Specifications For Single-Shell Waste Storage Tanks, OSD-T-151-00013, Westinghouse Hanford Company, Richland, Washington.

WHC 1996b, Operating Specifications for Tank Farms Leak Detection and Single-Shel1 Tank Intrusions Detection, OSD-T-151-00031, Westinghouse Hanford Company, Richland, Washington.

WHC, 1997a, Operating Specifications For Watch List Tanks, 0SD-T-151-00030, Lockheed Mart in Hanford Company, Richland, Washington.

WHC, 1997b, Operate the Standard B or Standard C Hydrogen Monitoring Systems, T0-040-040, Lockheed Mart in Hanford Company, Rich1and, Washington.

WHC-SD-WM-SAD-024, Safety Assessment for Tank 241-C-106 Waste Retrieva]

Project $W-320$, Westinghouse Hanford Company, Richland, Washington.

WHC-CM-6-1, Standard Engineering Practices, Section EP-4.2, "Testing Requirements," Westinghouse Hanford Company, Richland, Washington.

WHC-IP-1026, Engineering Practice Guidelines, Section EPG-4.2, "Testing" and Appendix K, "Test Plans, Specifications, Procedures, and Reports," Westinghouse Hanford Company, Richland, Washington. 


$$
\text { HNF-4034 Revision } 0
$$

Appendix A: Plant Operating Procedures Applicable to WRSS Operations During Process Test.

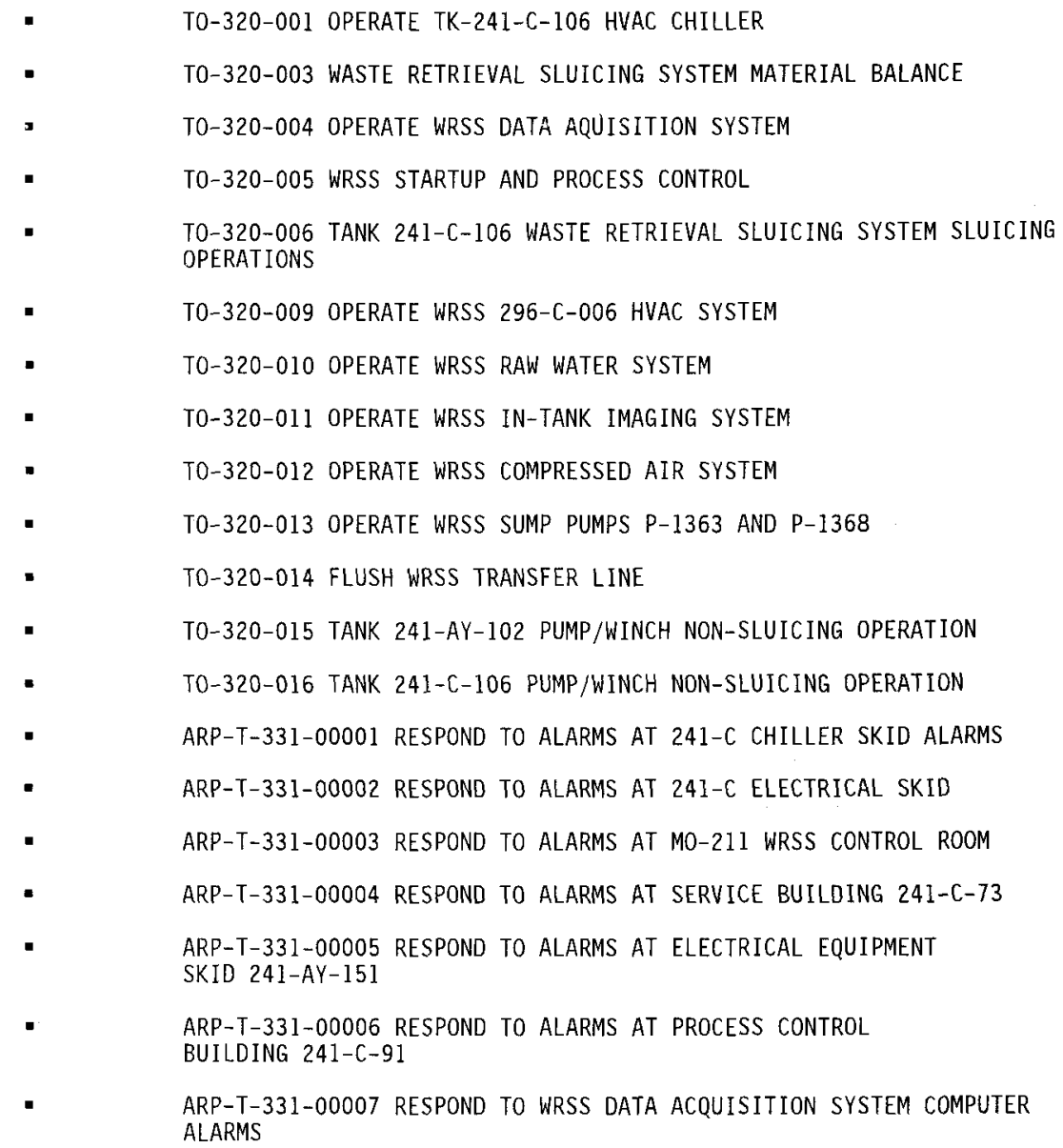


HNF-4034 Revision 0

Appendix B, HNF-0842: WHC-IP-0842 Volume IV Section 4.7

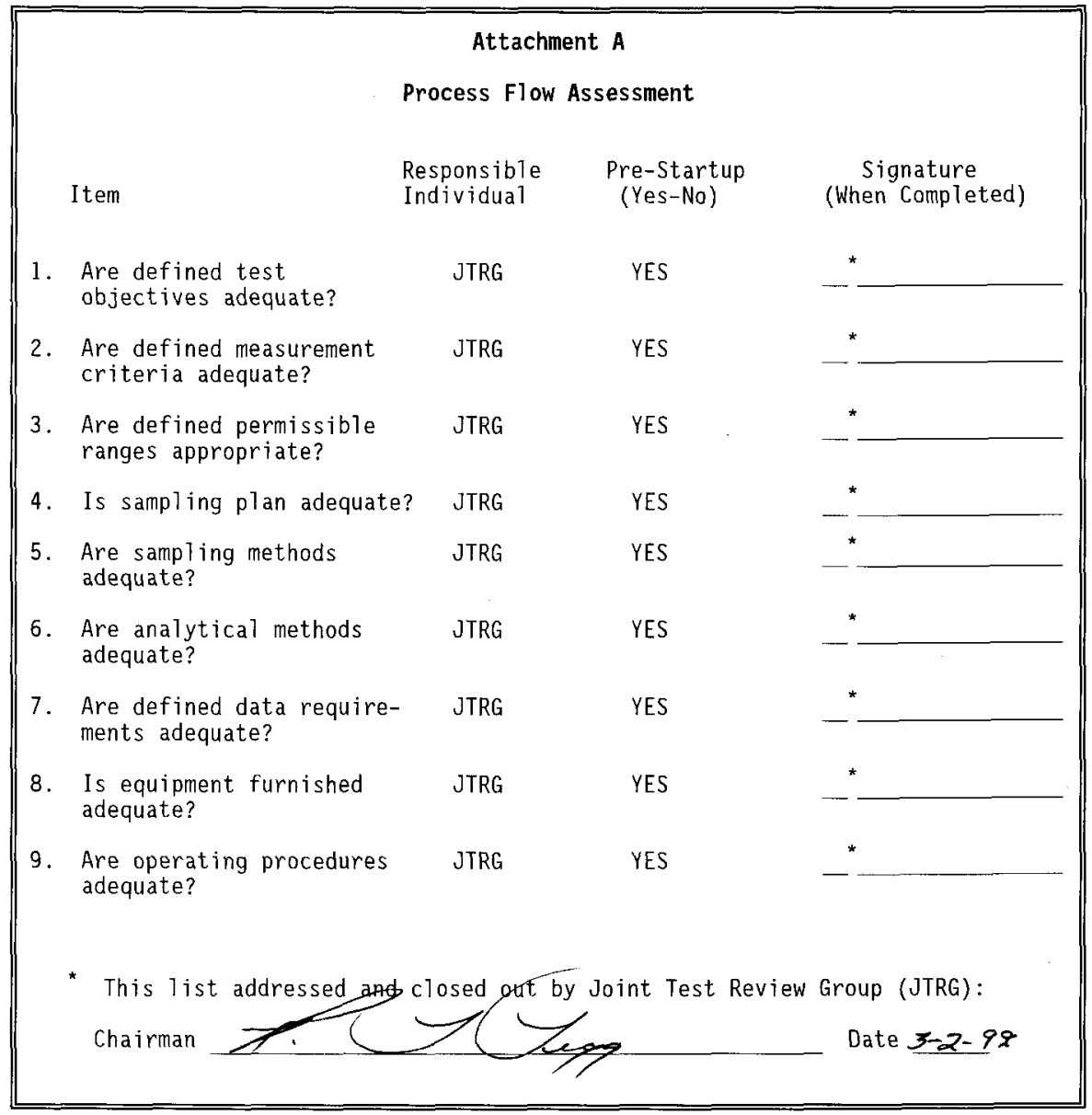

